\title{
CONTEXTUAL ANALYSIS ON PUBLIC SERVICE ADVERTISEMENTS FROM THE MINISTRY OF EDUCATION AND CULTURE: OVERSEAS WORKER
}

\author{
${ }^{1}$ Goziyah, 2 Maulana Yusuf, ${ }^{3}$ Imtihan Hanim \\ 1,2,3 University of Muhammadiyah Tangerang \\ E-mail: 1goziyah1812@gmail.com, ${ }^{2}$ my.maul24@gmail.com, ${ }^{3 i m t i h a n h a n i m 16 @ g m a i l . c o m ~}$
}

\begin{abstract}
This study aims to conduct a contextual analysis of Public Service Advertisements from the Ministry of Education and Culture: OVERSEAS WORKER. The approach in this research is qualitative with content analysis method. The source of the data in this study is the Public Service Advertisement from the Ministry of Education and Culture: OVERSEAS WORKER which is uploaded through the YouTube channel of the Ministry of Education and Culture of the Republic of Indonesia. From this research, four data were found that can be analyzed by contextual discourse analysis, which are divided into the principle of personal interpretation, the principle of locational interpretation, the principle of temporal or situational interpretation, and the principle of analogy.
\end{abstract}

Keywords: analysis, advertising, contextual, pragmatics

\section{INTRODUCTION}

Language is a device of communication that is always used by human to reach a goal. The use of language will always be developing a long with the development of the times. Goziyah and Yusuf (2019:120) point out that a language is a unique thing, it always develops and in each part of the world, the language is used differently of its variety. It shows that the language use cannot be separated from society life.

Moreover, Damayanti (2017:104) stated that the function of language is as communication tool in variety of environment, level, and variety of necessities, meanwhile the language is as social control that can control the communication to ease every person to get understanding each other. It is clear that a language has a function as communication device and as a social control in communication or in uttering a language in society life.

Based on the explanation above, it can be seen that a language is a tool of communication that is used by human in communicating and in interacting with society or individual as a social creature, the language usage is done to reach the goal from the listener and the speaker in communication. The language usage will always be developing a long with the times go on and it will last forever.

Using a language is not only to do direct communication between the individuals, but also it is delivered into written forms, such as a letter or a message, and it also can be delivered through communication media, such as audio, visual, audio-visual, or internet-based that can be watched. Arsyad (2016:4) stated that a media can be also implemented into learning process, so it can be defined as a learning source component and physical source that contains of instructional materials in the environment of learning. In its implementation, the usage of media in learning process can use the internet access and digitalization. Wati (2016:7) stated that the internet is a communication media that can help students to open their knowledge. Also, the internet can be used in education field, institution, business, and experts of many fields, in local or international range. One of the developments of the internet usage is a communication media that can be watched and can be understood from the content of information that is delivered is an advertisement, either it is broadcasted through radio show, television, based-internet show, and/or the advertisement advertised in mass media. 


\section{THEORETICAL FRAMEWORK}

An advertisement is used to give information for people. Amalia and Rustanta (2020:315) stated that an advertisement can be a part of communication which basically defines as a message transmission process that contains of information related to specific product, either a product or a service. The information transmission got from the advertisement is persuasive to persuade people to follow or to use what the advertisement offers.

Advertisement as a communication media must use easy language that can be understood by people, in other words, the chosen language in advertisement has no ambiguity meaning to prevent misunderstood from people. Pramesti and Martutik (2020:2) pointed out that a language is the most important communication tool used in advertisement and it should be an easy to be understood by the people. The ambiguity meaning will cause misinterpretation and the main information will not be delivered.

One form of communication, advertising exists to provide information about products and promotions, but does not rule out the possibility to provide information about public services. Mukaromah, et al (2017:221) reveal that public service advertisements are used to convey information, provide persuasion to the public (community) in order to orient social functions, not just economic orientation like commercial advertisements. The intended orientation can be in the form of people's views in a matter, in public service advertisements prioritizing social views, in contrast to commercial advertisements.

Besides giving persuasion from the advertisement, it must use an easy language that can be understood from people, therefore it will avoid misunderstood and it can cause a problem. Atika, et.al. (2018:189) pointed out that community service advertisement is a promotion media to get people's attention toward the advertisement informed and as a media of social service to be got to know by many people. Meanwhile, Pratiwi and Hidayat (2020:73) stated that generally, the community service advertisement in social marketing must use creative strategy in arranging a message and a usage of media, so it can change consumers' behaviour or people. In community service advertisement contains an information delivered to people about an awareness and sensitivity to social environment surrounding, for example, an information about environment, education, health, et cetera. Therefore, the society service advertisement can be shown to attract sympathy and emphaty from people who watch (to see and to listen) to participate based on the information shown in the advertisement.

Based on the above opinion, it can be concluded that public service advertising is a communication and promotion medium used to provide information and education to the public (persuasive) to the social community, this is done to make the public follow the information contained in public service advertisements.

One of the public service advertisements is the Public Service Advertisement from the Ministry of Education and Culture: Overseas Worker. The Ministry of Education and Culture of the Republic of Indonesia (Kemendikbud RI) is a ministry that carries out tasks in the field of education at all levels ranging from PAUD, primary and secondary education, to higher education. The Indonesian Ministry of Education and Culture broadcasts this public service advertisement to educate the public about an invitation to temporarily not return to their hometown during the Covid-19 pandemic. The Ministry of Education and Culture of the Republic of Indonesia through public service advertisements wants to convey that they are both pioneers of safety for all people in Indonesia. Education delivered by the Indonesian Ministry of Education and Culture regarding the spread of Covid-19 was carried out by uploading a public service advertisement video entitled 
Public Service Advertisement from the Ministry of Education and Culture: Overseas Worker through the Indonesian Ministry of Education and Culture's YouTube channel.

In the Public Service Advertisement from the Ministry of Education and Culture: Overseas Worker has her or his own purposes that can be studied through pragmatics. Bawamenewi (2020:201) argues that pragmatics is the study of real language, in human social life cannot be separated from interactions or relationships with other communities, both of which strengthen each other. Syahri and Emidar (2020:55) view that pragmatics is a science that examines (examines) the intent of speech. Language as a means of communication cannot be separated from the intent and meaning contained in speech, this is what is then studied in pragmatics.

Furthermore, Nisa, et al (2020:46) suggest that pragmatics studies a language without compromising the context of speech. The context of speech builds an understanding of the meaning of speech which makes context the main thing studied in pragmatics. It is the context of speech or what is more often called contextual which can then be analyzed using pragmatics. Furthermore, Oktavia and Zuliyandari (2019:230) explain that contextual discourse analysis is an analysis related to context based on the discourse text itself, context can also be interpreted as the background and reason for the utterance. There are four principles of interpretation in contextual discourse analysis, namely the principle of situational interpretation, the principle of personal interpretation, the principle of locational interpretation and the principle of analogy.

\section{RESEARCH METHOD}

This study uses a qualitative approach. Hudhana (2020:79) revealed that qualitative research is research that refers to data analysis methods and is descriptive, in this study the key instrument is the researcher. The method used in this study uses the method of content analysis (Emzir, 2015:28). Sulaeman and Goziyah (2019:226) state that content analysis is a message or information obtained that is systematically recorded, then interpreted by researchers, while in content analysis research the objectivity of researchers is very necessary so that an understanding of a content can actually be realized. The data used in this study is in the form of Public Service Advertisements from the Ministry of Education and Culture: OVERSEAS WORKER uploaded through the Indonesian Ministry of Education and Culture YouTube channel.

\section{RESULTS AND DISCUSSION}

Naturally, public service advertisements are media or facilities designed to provide information about social services in the community, such as health and fitness, education, arts and culture, and so on. Public service advertisements should optimize the use of media to make people start changing behavior (adapting) with new habits, according to the information that has been broadcast through public service advertisements.

In the Public Service Advertisement from the Ministry of Education and Culture: OVERSEAS WORKER has its own meaning which can be studied using contextual discourse analysis. The assessment of the context contained in this public service advertisement is of course based on the text (discourse or speech) contained in the public service advertisement. In contextual discourse analysis there are four principles of interpretation, namely (1) the principle of personal interpretation, (2) the principle of locational interpretation, (3) the principle of temporal or situational interpretation, and (4) the principle of analogy.

\section{a. The Principle of Personal Interpretation}

The principle of personal interpretation regarding speakers and speech partners (communicators and communicants) in a discourse in this case is public service advertisements. 
Globish (An English-Indonesian journal for English, Education and Culture)

Vol. 11, No.1, January 2022,

P-ISSN: 2301-9913, E-ISSN: 2597-9132

DOI: http://dx.doi.org/10.31000/globish.v7i2

Based on the discourse on the Public Service Advertisement from the Ministry of Education and Culture: OVERSEAS WORKER, the researcher determined Bagus as the main character of this public service advertisement, while his partner was his mother. Good character is described as a man who works in overseas lands and is far from his hometown.

\section{b. The Principle Of Locational Interpretation}

The principle of locational interpretation relates to the interpretation of the place where discourse events (speech) occur in public service advertisements, it is intended to help the public understand the content of the information conveyed in public service advertisements.

The location or place where the discourse event occurs in the Public Service Advertisement from the Ministry of Education and Culture: OVERSEAS WORKERS is a halfway house on an overseas land far from their hometown. It can be seen from the quote from the speech in the Public Service Advertisement from the Ministry of Education and Culture: OVERSEAS OFFICE below

Bagus : "Bagus pulangnya nunggu virus korona selesai ya, Bu...”

Bagus : ("It's good to go home waiting for the corona virus to finish, Mom...")

Ibu Bagus : "Ya makanya kamu pulang sekarang, di kampung aman kok,

Gus'."

Bagus' Mother: "That is why you should be home now, it is safer here, Gus"

In the quote (1) above, there are instructions for the location where the speech occurred, in this quote the location is obtained, this is a description of the initial location mentioned in the Public Service Advertisement discourse from the Ministry of Education and Culture: OVERSEAS WORKER. This is the initial utterance in the discourse that describes the location where Bagus is currently at, namely at the halfway house, where he lives overseas. Whereas in speech (2) it can be interpreted that in Bagus' hometown, where his mother lives is still in a safe zone from Covid19 (green zone) and no one has been confirmed to have been exposed to or positive for Covid-19.

\section{c. The Principle Of Temporal Or Situational Interpretation}

The principle of temporal or situational interpretation regarding the overall time description of the discourse (text and speech) contained in this case is a public service advertisement.

(3) Ibu Bagus : : "Ya Allah, semoga virus ini cepat selesai. Izinkan anak saya

biar bisa cepat pulang."

Bagus' mother: (Oh Allah, I hope this virus will end soon. Let my son do it:

Hurry home

Bagus : "Hari ini saya belajar berkorban, untuk orang tua yang saya

sayangi."

Bagus : "Today I learned to sacrifice, for the parents I love."

In the quote (3) above, it can be analyzed that there is a time information contained in the discourse of the public service advertisement above, it depicts the deep longing of the character Ibu Bagus for Bagus, and vice versa, but on Eid al-Fitr this time the longing must be temporarily 
P-ISSN: 2301-9913, E-ISSN: 2597-9132

DOI: http://dx.doi.org/10.31000/globish.v7i2

restrained. Time, due to suppress the spread of the Covid-19 pandemic. Meanwhile, in the quote from discourse (4) above, "today" can be interpreted as the day when Bagus informed his mother by telephone that he did not return to his hometown before Eid al-Fitr arrived, in order to maintain the health of his mother and all his neighbors (community) in the village.

\section{d. The Principle of Analogy}

The analogy principle relates to the basis used by speakers or interlocutors in understanding the meaning of the discourse context (speech) in public service advertisements. In identifying the intent of part or all of the discourse in this public service advertisement, the researcher gets the main point or essence of the problems faced by Bagus and his mother. Public Service Advertisement from the Ministry of Education and Culture: OVERSEAS WORKER is a form of people who are aware and care about health and immune strength for all levels and elements of society, to stop the spread of Covid-19 by temporarily not returning home or going home to reduce the spread of Covid-19 and Create a new cluster for the spread of Covid-19. This is imaged by Bagus in the public service advertisement, that it is not ego because of longing that is prioritized by putting aside care and empathy for others. The act of not going home or going home during the Covid-19 pandemic is a real action to support the government to reduce the number of Covid-19 spreads in Indonesia. If one of the people in the yellow, orange, red, and black zones travels long distances such as returning home or going home to the green zone, it is feared that the spread of Covid-19 will continue to soar and will slow down the handling of Covid-19 due to the large number of patients which must be handled with the limited number of medical personnel, as the front line in dealing with the Covid-19 pandemic.

\section{CONCLUSION}

Based on the research above, it can be concluded that public service advertisements are a medium of education and communication to the community, in order to make people change their behavior for the better according to the information contained in public service advertisements that have been broadcast through media that have been optimized for use. One of the public service advertisements that educates the public during the Covid-19 pandemic is a public service advertisement by the Ministry of Education and Culture, entitled Public Service Advertisement from the Ministry of Education and Culture: OVERSEAS WORKER uploaded through the Indonesian Ministry of Education and Culture's YouTube channel. In this advertisement, the Ministry of Education and Culture is educating the public to temporarily refrain from traveling long distances, such as returning home or going home to reduce the spread of Covid-19 in Indonesia. Public Service Advertisement from the Ministry of Education and Culture: OVERSEAS WORKER, in the contextual analysis in this study found four data consisting of the principle of personal interpretation, the principle of locational interpretation, the principle of temporal or situational interpretation, and the principle of analogy.

\section{REFERENCES}

Amallia, F dan Agustinus, R. 2020. "Analisis Makna Iklan Indomie Versi "Selera Yang Selalu Menemani"”. Jurnal Ilmu Komunikasi dan Bisnis - Sekolah Tinggi Tarakanita. Volume 5 Nomor 2 (Tahun 2020) Halaman 313-344. (http://jurnal.stikstarakanita.ac.id/index.php/IIK/article/download/353/pdf).

Arsyad, A. 2016. Media Pembelajaran. Jakarta: PT RajaGrafindo Persada.

Atika, J dkk. 2018. "Iklan Layanan Masyarakat Peduli Sampah". PROPORSI: Jurnal Desain, Multimedia, dan Industri Kreatif - LPPM Universitas Potensi Utama Medan. Volume 3 Nomor 2 (Tahun 2018) Halaman 188-197. (https://e-journal.potensiutama.ac.id/ojs/index.php/PROPORSI/article/view/565/749). 
Globish (An English-Indonesian journal for English, Education and Culture)

Vol. 11, No.1, January 2022,

P-ISSN: 2301-9913, E-ISSN: 2597-9132

DOI: http://dx.doi.org/10.31000/globish.v7i2

Bawamenewi, A. 2020. "Analisis Tindak Tutur Bahasa Nias Sebuah Kajian Pragmatik”. Jurnal Review Pendidikan dan Pengajaran - Universitas Pahlawan. Volume 3 Nomor 2 (Tahun 2020) Halaman 200-208. (http://journal.universitaspahlawan.ac.id/index.php/jrpp).

Damayanti, W. 2017. "Register Percakapan Anggota Kesatuan Lalu Lintas Polresta Pontianak: Kajian Sosiolinguistik" Aksara Kemendikbud RI. Volume 29 Nomor 1 (Tahun 2017) Halaman 103-116. (http://aksara.kemdikbud.go.id/jurnal/index.php/aksara/article/view/104).

Goziyah dan Maulana, Y 2019. "Bahasa Gaul (Prokem) Generasi Milenial dalam Media Sosial". Prosiding Seminar Nasional Bulan Bahasa (Semiba) 2019 - Universitas Bengkulu. Tahun 2019 Halaman 120-125. (https://semcon.unib.ac.id/index.php/semiba/Semiba/schedConf/presentations).

Hudhana, W,D. 2020. Modul Keterampilan Menulis Ilmiah. Tangerang: Pusat Bahasa Universitas Muhammadiyah Tangerang.

Mukaromah, dkk. 2017. "Iklan Layanan Masyarakat dan Respon Khalayak". Islamic Communication Journal - Universitas Islam Negeri Walisongo. Volume 2 Nomor 2 (Tahun 2017) Halaman 219-235. (https://journal.walisongo.ac.id/index.php/icj/article/view/2710/1540).

Nisa, H, K dkk. 2020. "Kesantunan Berbahasa pada Peribahasa Indonesia Bermakna Sindiran: Kajian Pragmatik". HUMANIKA - Universitas Diponegoro. Volume 27 Nomor 1 (Tahun 2020) Halaman 44-58. (http://ejournal.undip.ac.id/index.php/humanika).

Oktavia, W dan Diyan, Z. 2019. "Analisis Wacana Tekstual dan Kontekstual dalam Naskah Drama Bunga Rumah Makan Karya Utuy Tatang Sontani" LINGUA: Jurnal Bahasa, Sastra, dan Pengajarannya - Universitas Negeri Semarang. Volume 15 Nomor 2 (Tahun 2019) Halaman 223-233. (http://journal.unnes.ac.id/nju/index.php/lingua).

Pramesti, A, P dan Martutik. 2020. "Laras Bahasa Iklan pada Media Sosial Instagram”. BASINDO: Jurnal Kajian Bahasa, Sastra Indonesia, dan Pembelajarannya - Universitas Negeri Malang. $\begin{array}{lllll}\text { Volume } & 4 & \text { Nomor } & 1 & \text { (Tahun 2020) Halaman 1-16. }\end{array}$ (http://journal2.um.ac.id/index.php/basindo).

Pratiwi, S, A. dan Dasrun Hidayat. 2020. "Iklan Layanan Masyarakat Covid-19 di Media Sosial dan Perilaku Masyarakat di Jawa Barat”. Komunikologi: Jurnal Ilmiah dan Ilmu Komunikasi Esa Unggul. Volume 17 Nomor 2 (Tahun 2020) Halaman 71-82 (https://komunikologi.esaunggul.ac.id/index.php/KM/article/view/249/226).

Syahri, N. dan Emidar. 2020. "Analisis Tindak Tutur Lokusi dan Ilokusi dalam Program Ini Talkshow NET TV Sebagai Kajian Pragmatik". Jurnal Pendidikan Bahasa dan Sastra Indonesia dan Daerah - Universitas Negeri Padang. Volume 9 Nomor 2 (Tahun 2020) Halaman $55-63$. (http://ejournal.unp.ac.id/index.php/pbs/article/view/108991/103591).

Wati, E, R. 2016. Ragam Media Pembelajaran. Surabaya: Penerbit Kata Pena. 